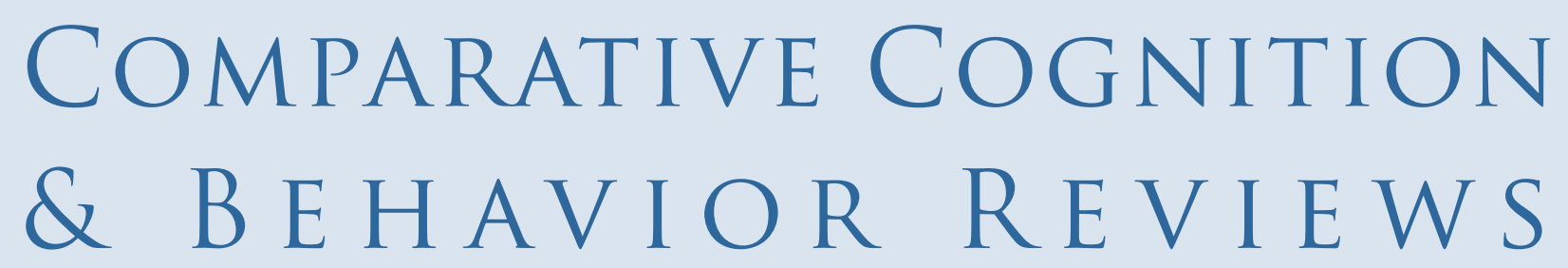

\title{
From Saliva to Faeces and Everything in Between: A Guide to Biochemical Analysis Using Animal Samples for Biomarker Detection
}

\author{
Simon R. Clegg and Stefan H. Millson \\ University of Lincoln, School of Life Sciences
}

Over the last decade, interest in the emotional states and stress levels of animals has grown. These emotional states can have secondary effects for owners; for example, if an animal becomes aggressive, this can lead to relinquishment or even euthanasia. In addition, long-term stressful situations can have serious health impacts on animals and can affect meat quality in livestock. A variety of methods can be used to investigate biomarkers in animals, and many sample types can be taken to facilitate this. The choice of assay will often depend on the animal under investigation and practicalities of obtaining the sample. The assay choice can also be dependent on testing conditions such as the field versus laboratory, samples taken, costs, and the desired results. There is also the question of the timescales of the investigated response: Do you want to test what happened over the last month? Last week? Yesterday? Or within the last hour? This review highlights some of the pros and cons of the different samples and the different methods for biomarker analysis in animals. Studies can be made or broken based on the type of samples taken, and what aspects are to be investigated, and this simple decision can make a world of difference to the results of an investigation. Careful planning and thought before starting a study can make the difference between a scientific breakthrough with animal welfare and husbandry implications and poor results that are of little use to man or beast.

Keywords: biochemical analysis, ELISA, saliva, blood, hair, faecal

\section{Introduction}

Careful selection and analysis of biological samples is vital for accurate quantification of animal health, condition, and welfare. This review covers some of the key considerations for selecting the biological sample for analysis and the type of biochemical test(s) required to analyse the biological markers (biomarkers) present. As an extra complexity, multiple biomarkers can be used for similar types of analysis; for example, to evaluate stress, cortisol, amylase, or even IgA are potential biomarkers (Hong et al., 2019; Mack \& Fokidis, 2017; Muneta et al., 2010). As you would imagine, these different biomarkers are all present in the host animal, but they will be at different levels or even totally absent depending on the choice of biological samples (blood plasma, saliva, urine, faeces, etc.). The type of biological assay, or the number of steps needed to process/extract the biomarker, varies both with the type of sample and with the selected biomarker. These biomarkers are often hormones but can also be enzymes, other proteins, or metabolites (including hormone metabolites). These factors might even require compromises between selecting accuracy over easy, rapid, or in-field testing, when selecting the sample and/or biomarker to be investigated.

This review is divided into two major sections: The first section covers the aspects of selecting samples, different sample types, and examples of biomarkers that can be measured from these samples. The second section mostly focuses on the different types of biochemical assays that can be used to measure biomarkers and simple descriptions of how these assay work or may be used. Given the 
enormous breadth of the review, we have provided general examples and citations for more specific examples covering the major sample types, commonly used biomarkers, and biochemical assays. The goal of the review is to provide a first resource for researchers interested in studying biomarkers to complement behavioural analysis. This article should not be considered a complete guide. We urge readers who are planning to use any of the techniques described here to read more detailed information in the many publications we have cited, because many of our general rules of thumb may not apply to specific implementations.

\section{Choosing the Ideal Sample}

Selecting the ideal physical sample is incredibly important. Although most assays are available to run either on site or in a laboratory, this may not be the case for all samples. The selection of sample type is dependent on the biomarker(s) to be measured, the types of assays available to measure these biomarkers (see the Types of Biochemical Test section for further information), and the ability/ availability to collect the sample type. Availability will depend on many factors, not least the ability to collect invasive samples, such as blood, and the research project questions/aims (Mormède et al., 2007). It is important to mention that the correct ethical and legal licences must be in place before samples are obtained from animals. In addition, licences may also be needed for working with certain species, such as Convention on International Trade in Endangered Species of Wild Fauna and Flora (CITES) species, or for transportation of samples across borders or into countries because of biosecurity concerns (Animal Science Procedure Act [ASPA], 1986). As an example, a schematic diagram for selecting the ideal sample for studying stress responses is shown in Figure 1.

\section{Blood}

Blood is generally regarded as the gold standard sample, but sampling is highly invasive and as such may require licenses, such as a Home Office Licence in the

Author Notes: Simon R. Clegg and Stefan H. Millson, School of Life Sciences, University of Lincoln, Lincoln, LN6 7DL, United Kingdom.

Correspondence concerning this article should be addressed to Stefan H. Millson atsmillson@lincoln.ac.uk.

Acknowledgments: Research was supported by The Dogs Trust canine welfare grant " $\alpha$-Amylase as a Non-Invasive Biomarker for Stress in Dogs. ”
UK (ASPA, 1986). It is also important to remember that the process of taking blood can alter the level of stress hormones in the animal, particularly when an animal is not keen on being handled (e.g., sheep; Romero \& Read, 2005). In other cases, when animals require capture in the wild, the stress of the process may induce glucocorticoid hormone release, so ideally samples should be taken within a few minutes of capture while ensuring sample collector safety (Romero \& Read, 2005).

Blood samples have to be processed correctly-commonly by low-speed centrifugation or clotting into sedimentation layers such as the cells, buffy coat, or plasma/ serum - to ensure that the layer with the biomarker is retained (Bielohuby et al., 2012). It is also worth noting that a substantial difference exists, especially for protein concentrations such as fibrinogen, between serum and plasma, so care must be taken to ensure that the correct one of these two is chosen (plasma has fibrinogen and clotting factors, but they are absent or greatly reduced in serum samples).

Blood samples can be stored with relative ease at room temperature or chilled while sampling, before ideal storage at $-80{ }^{\circ} \mathrm{C}$ for sera and plasma (Bielohuby et al., 2012; Lombardi et al., 2012). However, biomarker stability can vary with temperature, allowing conformational changes or proteolytic cleavage (Reimers et al., 1983). Freeze-thaw cycles can also cause degradation of some hormones, so ideally, the samples that are to be used to detect multiple hormones should be aliquoted out into several smaller volumes for single use (Bielohuby et al., 2012).

It is also important that dilution of blood or serum sample, even by introduction of an anticoagulant as commonly occurs in a vacutainer, is taken into account with final calculations, as it may affect the results (Bowen et al., 2010; Kontny et al., 2011; Lippi, Franchini, et al., 2006). Haemolysis, which can be caused by inappropriate sample handling and storage, can also lead to dilution and potential contamination of the sample and should be prevented where possible (Bellomo et al., 2012; Koseoglu et al., 2011; Lippi, Salvagno, et al., 2006).

Additionally, and importantly, there is a difference in measurable blood analytes, especially with rodents, for which there is a large difference in the site from which the blood sample is obtained (e.g., tail vain, tail tip sampling, jugular vein, cardiac puncture; Aasland et al., 2010; Arola et al., 1980; Christensen et al., 2009; Fitzner Toft et al., 2006; Vahl et al., 2005). Therefore, it is worth considering where you would take the terminal blood sample from if an animal is to be euthanised. 
There are also biomarker variations on a daily, monthly, postfeeding, and even sometimes yearly circadian rhythm with hormones such as testosterone and progesterone, as has been shown in maned wolves, and in seals (Greig et al., 2007), which show increased peaks in certain seasons (Maia et al., 2008).

Although blood is a complicated mixture of a large number of proteins, it offers a rapid or even instantaneous insight into stress hormones. Indeed, it may be so fast that unless samples are obtained very rapidly, the stress of being handled may create issues and inflate stress hormone levels.

\section{Saliva}

Saliva is a relatively easy-to-obtain sample and can contain various hormones, including cortisol (Cobb et al., 2016; Cook et al., 2013; Wenger-Riggenbach et al., 2010). As cortisol is a lipid soluble hormone, it crosses cellular membranes, allowing for its detection in saliva within 15 min of a stressor being applied, making it an ideal sample for rapid stress hormone detection (Dickerson \& Kemeny, 2004; Gunnar \& Vazquez, 2006; Kirschbaum et al., 1993; Shirtcliff et al., 2015). This rapid release and ease of testing has led to development of point-of-care devices to assess stress in both humans and animals (Choi et al., 2014; Kaushik et al., 2014; Nara et al., 2010; Zangheri et al., 2015).

Depending on how sampling is performed, it may also require a licence. For example, within the United Kingdom, the ASPA (1986) means that you can swab around the outside of the teeth but a licence is required to enter the buccal cavity, as this is considered an invasive sample. In addition, the volume of saliva can sometimes be small, from around $100 \mu 1$ from dogs (personal experience) to around 500-750 $\mu$ from equids using the Equi$\mathrm{Sal}^{\circledR}$ saliva collection swab (Austin Davis Biologics Ltd., Northamptonshire, UK).

A wide range of studies have used saliva from various animals to test for different hormones associated with behaviour and stress, including cortisol (Cobb et al., 2016; Cook et al., 2013; Wenger-Riggenbach et al., 2010), luteinizing hormone (Srinivasan et al., 2020), oxytocin (MacLean et al., 2018), vasopressin (MacLean et al., 2018), prolactin (Gutiérrez et al., 2019), and testosterone (Kutsukake et al., 2009).

Studies have also shown a strong correlation between cortisol in blood and in saliva, suggesting that saliva may be a useful proxy for blood sampling, avoiding invasive sampling (Fell et al., 1985; Greenwood \& Shutt, 1992; Negrão et al., 2004), although other studies disagree (Dzviti et al., 2019). It does have the advantage of being repeatable multiple times in a relatively short period (Koyama et al., 2003). However, this can be difficult in field situations for wild animals, but novel methods of saliva collection have been devised and used successfully (Higham et al., 2010; Smiley et al., 2010).

Care also needs to be taken when choosing the method for saliva collection. Potentially, swabs can be contaminated with food debris, and even plant hormones can interact with immunoassay antibodies (Dabbs, 1991; Granger et al., 1999), and some biomarkers may adhere to the cot-

Figure 1. A flowchart diagram to aid with the selection of the ideal sample for the study which you wish to undertake. Note that this may differ from country to country as licencing requirements vary. $\mathrm{Y}=$ yes; $\mathrm{N}=$ no.

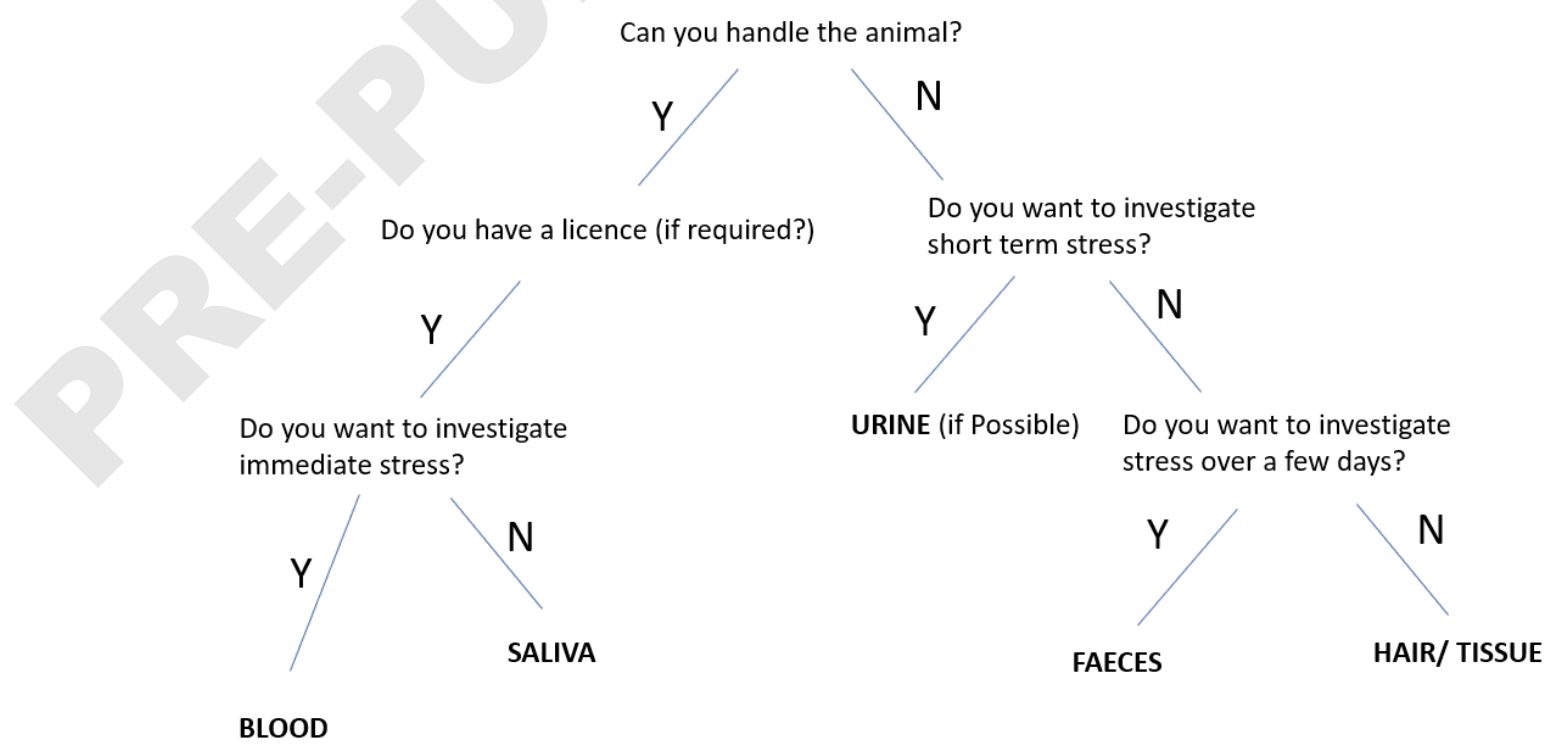

Volume 16, 2021 
ton swab and thus escape detection (Shirtcliff et al., 2001). Processing of saliva can be difficult if the sample is highly viscous, and samples can precipitate after a freeze-thaw cycle (Read et al., 1990; Riad-Fahmy et al., 1982). Once again, several freeze-thaw cycles can alter the concentration of hormones (Gröschl et al., 2001).

Additionally, salivary flow rate can influence results by diluting potential hormones of interest. This can be exacerbated by many factors, including increased temperature, food and liquid intake (Elmér \& Ohlin, 1971; Ito et al., 2001; Jacques et al., 1989), and exercise (Colussi et al., 2018). Food intake can cause errors in hormone measurement (Laudenslager et al., 2006; Magnano et al., 1989), and care must be taken to avoid causing bleeding and getting blood contamination of the swab, as this can alter the hormone concentration (Dzviti et al., 2019). Even an easy-to-obtain sample may require considerably more planning than one might think (Kalliokoski et al., 2019; Koren et al., 2019).

\section{Hair or Other Tissue}

Hair and tissue are rapidly developing areas of interest for studies associated with hormones and behaviour/ cognition. Hair presents a simple, relatively easy-to-obtain sample but can prove difficult if working with certain animals, such as wild cats, because of concerns about collecting samples safely.

Although mainly used for human medicine so far, hair can act as a nice proxy for long-term analysis of hormones that are encompassed into the hair during its growth (Schweikert \& Wilson, 1974). Studies often focus on a variety of hormones, including testosterone, oestradiol, cortisone, progesterone, cortisol, and androstenedione (Chen et al., 2013; Gao et al., 2013, 2016; Grass et al., 2016; Kapoor et al., 2014; Yang et al., 1998).

Complications exist with using hair for analysis of some hormones; for example, cortisol levels can vary with the hair's location on the body, so standardisation of sampling area is important to allow for comparisons (Carlitz et al., 2015; Heimbürge et al., 2019; Mesarcova et al., 2017; Terwissen et al., 2013; Yamanashi et al., 2013). Thus, collection of random hair from nests, traps, or fences, such as from rodents or sheep, can prove problematic (Heimbürge et al., 2019). The reasons for these variations remain unclear but may be associated with factors such as the level of sunlight to which a body part is exposed (Grass et al., 2016).

Hormone degradation does not appear to be a great concern with hair, meaning that the sample can easily be stored at room temperature without the need for desiccation or freezing (Accorsi et al., 2008), but washing hair samples is important to limit contamination with sweat, urine, or faecal matter (Chen et al., 2013; Ferrero \& Liberles, 2010; Gao et al., 2016; Musshoff \& Madea, 2007; Sheriff et al., 2011).

Hormone concentration can vary with factors that influence the growth rate of the hair; these factors can include age, part of the body, sex, breed, and species (Heimbürge et al., 2019). In addition, concentrations can vary with hair colour, as seen in dogs and chimpanzees (Bennett \& Hayssen, 2010; Taylor et al., 2015; Wennig, 2000; Yamanashi et al., 2013). Questions also remain about the effectiveness of measuring hormones in hair strands. Most hormones are concentrated in the bulb of the hair and not completely incorporated into the hair strand as it grows, so hormone concentration is highly dependent on the part of the hair that is analysed (Keckeis et al., 2012; Stubsjøen et al., 2015).

As an alternative to hair, a sample of claw tissue, such as that obtained during routine trimming of nails in animals, may be used. This tissue provides assessment of stress hormones in the animal over a long period (Matas et al., 2016). A correlation has been shown between hair and claw cortisol in newborn dogs (Veronesi et al., 2015). For avian species, feathers can be used rather than hair (Matas et al., 2016).

Thus, hair, feathers, and claws can offer a simple, and in some cases easy-to-collect, sample, but some level of planning is required to ensure that results obtained from these samples are comparable and that differences are not due to different sample types.

\section{Faeces}

Faeces is possibly the easiest sample to obtain, as it is left naturally by all animals. Perhaps an obvious statement, faeces is a dirty sample filled with various hormones and enzymes at different stages of metabolism, animal gut microbiota, food remains, and other bits that may interfere or inhibit certain reactions such as polymerase chain reaction (PCR; El-Bahr et al., 2005; Lepschy et al., 2007; Palme, 2005). Indeed, differences in the gut microbiota can lead to differences in hormone metabolism and breakdown, so this may affect results of faecal hormone analysis (Antwis et al., 2019; Hooda et al., 2013).

Faecal sampling has proven particularly useful for different research focuses, including long-term stress, seasonal hormone patterns, and pregnancy status (Cizauskas et al., 2015; Garnier et al., 1998; Hadinger et al., 2015; Hernandez et al., 2018; Isobe et al., 2005; Nemeth et al., 2016, Schwartzenberger et al., 1996; Wasser et al., 1991; Wheeler et al., 2013). This sampling is commonly used 
to investigate the presence of steroidal hormones, such as oestrogens, androgens, and progestins for reproductive status determination and glucocorticoids for stress analysis (Amaral, 2010; Goymann et al., 2002; Harper \& Austad, 2000; Kotrschal et al., 1998).

However, the use of faeces for hormone detection is somewhat limited by heavily degraded samples because of the harsh conditions of the gut as well as the actions of the bacteria in the microbiome (Antwis et al., 2019; Hooda et al., 2013). As such, it is important that faecal samples are collected rapidly postdefecation and frozen to prevent further bacterial degradation of hormones (Hodges \& Heistermann, 2011; Millspaugh \& Washburn, 2004), as this will affect the results (Palme, 2005, 2019). Where freezing is not possible, such as in field situations, rapid drying the sample may prevent significant degradation, such as can be achieved by using alcohol to remove water (Palme, 2005), but this is not always ideal. Addition of sodium azide or other acids can aid preservation of hormones in alcohol at room temperature, although these harmful chemicals are dangerous to the environment and may not be suitable in the field (Whitten et al., 1998). More recently, rapid field extraction has given a more accurate picture of the hormones that are present in a faecal sample (Beehner \& Whitten, 2004; Kalbitzer \& Heistermann, 2013; Whitten et al., 1998; Ziegler et al., 2005).

Biomarkers are not always evenly distributed throughout a faecal sample, so the part of the sample that is taken needs to be carefully planned. This is particularly true for large animals, which produce a large faecal sample, such as cattle and elephants. The same part of the sample should be taken to allow for appropriate comparison between samples (Hadinger et al., 2015; Peter et al., 2018). Then homogenisation is required prior to analysis; removal of large pieces of nondigested foods such as seeds and insects will aid in this (Millspaugh \& Washburn, 2004; Palme, 2005).

Difficulties can also arise in collection and potential contamination, especially urine contamination, which can increase concentrations of some hormones, skewing results (Hay et al., 2016; Schönning et al., 2002). Despite difficulties, studies have been carried out on aquatic animals (Amaral, 2010). A major positive to this sample is that there are limited diurnal variations of hormones within faeces, unless there is a very rapid gastrointestinal tract transit time (Goymann, 2005, 2012; Millspaugh \& Washburn, 2004).

Although a simple sample to collect in many cases, faeces needs some thought and some standardising to ensure that the results can be appropriately analysed and compared.

\section{Urine}

Urine is a mixture of waste products and hormones that are commonly excreted as conjugated water-soluble forms. They are often an indication of the presence of hormones over a few hours rather than an instantaneous indication as seen with saliva (Bouatra et al., 2013).

Urine is already widely used for detection of pregnancy hormones in humans, and the detection of human chorionic growth hormone (Chard, 1992) is used in home pregnancy test kits. Urine is also useful in disease diagnostics, such as monitoring diabetes in humans and in dogs (Hess et al., 2000).

Urine can be relatively easy to obtain from some animals (e.g., through a swab of the bottom of the cage) but relatively difficult from others and may require some training of the animals (Kurien et al., 2004; Laule et al., 1996). When working with wild animals, collection of this sample can be even more difficult, but methods have been developed (Danish et al., 2015; Knott, 1997). Urine has been used to detect a variety of peptide hormones, such as cauxin (McLean et al., 2007), trypsinogen activation peptide (Allen et al., 2006), c-peptide (Polonsky et al., 1984), oxytocin (Mitsui et al., 2011; Nagasawa et al., 2009), vasopressin (Dolph et al., 1962), and thyroid hormones (Goff et al., 1986), as well as certain immune parameters, particularly linked with infection with various pathogens (Dorward et al., 1991; Ravnik et al., 2014).

Although some biomarkers are considered to be stable in urine at room temperature for up to $24 \mathrm{hr}$, some degradation may occur because of the bacteria within the sample (Grant \& Beastall, 1983). Equally, urine samples should be centrifuged to remove particulate matter, and care should be taken when freezing urine samples, as this may lead to further sample degradation (Heistermann, 2010).

One should bear in mind that the volume of urine, which is linked to the hydration of the animal, will have an impact on the concentration of hormones. For example, a well-hydrated animal will produce higher volumes of urine than a dehydrated animal, and more dilute urinary hormones (Miller et al., 2004). To counter this issue, creatinine is sometimes used as a counterbalance, but this is also subject to many fluctuations based on diet, age, sex, breed, kidney function, and so on (Carrieri et al., 2000; Miller et al., 2004; Thompson et al., 2012).

Urine also allows for an investigation into varying concentrations of hormones over a day, with a sample that is easier to collect than saliva in some cases (Heis- 
termann, 2010). However, this can cause issues, as certain hormones can be naturally increased at certain times of day. This increase may not be in response to a stressor; for example, in some species of monkey cortisol levels can be higher in the morning than at other times of day (Davis et al., 2005; Muller \& Lipson, 2003; Smith \& French, 1997). This is also true for dogs, which show variation during the day and night (Gordon et al., 1985; Kolevská et al., 2003). Therefore, throughout the study the timing of sampling should be as close to the same as possible. If similar timing cannot be maintained, urinary hormones should be analysed with caution.

Although a urine sample is easy to obtain for some animals, several other aspects need to be factored into studies to make sure that the results are reliable and easy to interpret. Whatever sample is chosen, the extraction method is important. Method is discussed later in this article.

\section{Types of Biochemical Tests and Their Applications}

Commonly, the selection of a biochemical test is determined by the choice of biomarker and the type of sample available for its isolation. Key considerations in selecting the most appropriate test(s) are briefly discussed next and summarised in Table 1. These considerations include the type of biomarker (chemical, protein, DNA/RNA), how much sample can be collected (as some methods require as little as $1-10 \mu 1$ of sample but other tests require several milliliters), budget, and whether the test needs to be performed in situ.

\section{Chemical Assays}

Chemical detection of biomarkers directly measures a chemical in a biological sample by causing a reaction to report the presence or amount of the chemical. Chemical assays are routinely used to detect and measure the levels of sugars or proteins in urine, for example (Boag et al., 2019; Shropshire et al., 2018). They are comparatively inexpensive compared with antibody test assays, which are quick to perform but can lack sensitivity. An example of rapid, easy-to-use chemical assays are "dipstick" assays. A "dipstick" is dipped briefly (usually for 1-15 s) into the biological liquid being assayed, then left for about $15 \mathrm{~s}$ for the reaction to occur. The readout is colorimetric, and the amount of colour produced is proportional to the amount of chemical present. The systems used for diabetes testing in animals is a common example. The dipstick colour can be compared with a colour range chart supplied with the assay kit to provide semiquantitative data, which allows for rapid in-field measurements of proteins, chemicals, and $\mathrm{pH}$ by comparatively untrained researchers (Athanasiou et al., 2018; Boag et al., 2019).

\section{Enzyme-Linked Assays}

Enzyme-linked assays are commonly used either as a reporter system "linked" to another chemical reaction, in order to get a quantitative readout, or to amplify the readout of another reaction to increase assay sensitivity. Enzyme-linked assays are, in general, more complex than standard chemical or enzymatic assays. They are often used to measure enzymatic activity and have the ability to amplify the reporter system so that low levels of activity can be more easily measured. These assays have

Table 1. A Table of Considerations for Selecting Biochemical Test Types or Biomarkers.

\begin{tabular}{llll}
\hline \multicolumn{1}{c}{ Test Type } & \multicolumn{1}{c}{ Biomarker } & \multicolumn{1}{c}{ Method Output } & \multicolumn{1}{c}{ Limitations } \\
\hline Chemical & Chemicals and proteins & $\begin{array}{l}\text { Mostly colorimetric reporter systems } \\
\text { or colour change }\end{array}$ & Sensitivity of the test. Amount of sample required. \\
\hline Enzyme-linked assay & Chemicals, proteins & Mostly colorimetric reporter systems & Sensitivity of the test. Amount of sample required. \\
\hline Antibody tests & Biomolecules and chemicals & $\begin{array}{l}\text { Lateral flow positive/negative read- } \\
\text { out or colorimetric reporter systems }\end{array}$ & $\begin{array}{l}\text { Availability of antibody test being commercially } \\
\text { available }\end{array}$ \\
\hline Enzyme activity & Enzymes & Mostly colorimetric reporter systems & Sensitivity of the test. Amount of sample required. \\
\hline PCR test & RNA or DNA & $\begin{array}{l}\text { Graphic or gel band. Indicator of } \\
\text { presence or copy number. }\end{array}$ & $\begin{array}{l}\text { Availability of RT-PCR facilities/ equipment. Ability } \\
\text { to extract RNA/DNA from the samples. }\end{array}$ \\
\hline Proteomics & Proteins & $\begin{array}{l}\text { Mostly colorimetric reporter systems } \\
\text { or identification of modifications by } \\
\text { affinity isolation then either mass } \\
\text { spectrometry or western analysis us- }\end{array}$ & Cost. Analysis of PTMs/services. \\
& & ing PTM specific antibodies & \\
\hline Mass spectrometry & Chemicals and proteins & $\begin{array}{l}\text { Graphic/tabulated data. Indicator of } \\
\text { presence or amount present. }\end{array}$ & $\begin{array}{l}\text { Potentially required as an external service be- } \\
\text { cause of expertise and equipment cost }\end{array}$ \\
\hline
\end{tabular}


multiple stages and require dedicated laboratory systems/ equipment. Not all enzyme-linked assays require the use of antibodies but simply use linked enzyme systems as a method of reporter amplification for detecting the activity of enzymes at very low concentrations. Antibody detection systems such as Enzyme Linked Immunosorbent Assays (ELISAs) often rely on enzyme-linked reporter systems to amplify the colorimetric quantitative readout systems. These ELISA systems are becoming veterinary specific, instead of re-protocoling human ELISA kits and systems (Lane et al., 2018).

\section{Antibody Test Assays}

Antibody test systems are normally divided into two categories: those that test for the presence of an antibody in a biological sample, and those that use antibodies to test for chemicals in biological samples. One of the simplest tests that uses antibodies to detect chemicals present in biological samples is the lateral flow test kit, commonly used as a pregnancy test device. This kit can be used for early detection of conception onsite or in the field (Ambrose et al., 2007). However, with the massive increase in recent years in the range of ELISAs available for detecting and the quantification of molecules, most key biomolecules can be quantified using ELISAs. These systems vary enormously in sensitivity and the types of samples for which they are suitable, and the cost ranges from around $£ 200$ (US\$283) for the commonly used/available kits to $£ 1000$ (US\$1,417) or more for specialist kits.

ELISA assays are most commonly used in 96 well microplate format and normally allow around 80 samples (about 40 samples if performed in duplicate or about 24 samples in triplicate; see Figure 2) to be analysed. Up to 16 wells are required for calibration standards and controls. (These are important in order to confirm that the assay works correctly. They should not be skipped or reduced, however tempting it may seem.) As well as standard protocols, ELISAs can be modified for use in novel techniques-for example, in assessing chronic stress in dogs using cortisol as a biomarker extracted from nails as the biological source (Mack \& Fokidis, 2017).

Sadly, the choice of ELISA is not always simple, as there are many different types. Generally, they can be classified into four main groups:

- Direct ELISA: Antigen (target) is bound directly to the well of the plate and directly assayed by a conjugated reporter antibody.
- Indirect ELISA: Similar to the direct ELISA, but a second, conjugated antibody is used to detect the first unlabelled-antibody that bound the antigen.

- Sandwich ELISA: Antigen (target) is captured between two antibodies; one is bound to the plate and captures the antigen, and the other is added later for detection, thus forming a complex like a "sandwich."

- Competitive ELISA: Measures the amount of sample by quantification of its interference/competition with an expected signal.

Potentially, the competitive ELISA is most useful for quantification of biomarkers because it allows accurate quantification of the levels present in biological samples (Cell Signaling Technology, n.d.), though it depends on the biomarker. Plotting calibration curves and calculating values for unknown samples can be time-consuming and potentially challenging. However, many free-to-use ELISA analysis websites will plot the

Figure 2. An example ELISA 96 well plate layout. A) Triplicates for known standards S1-7 (green), Blank (B1, grey), and unknown samples (U1-40, yellow). B) ELISA plate with TMB substrate producing a yellow colour measurable at $450 \mathrm{~nm}$ on a plate reader.

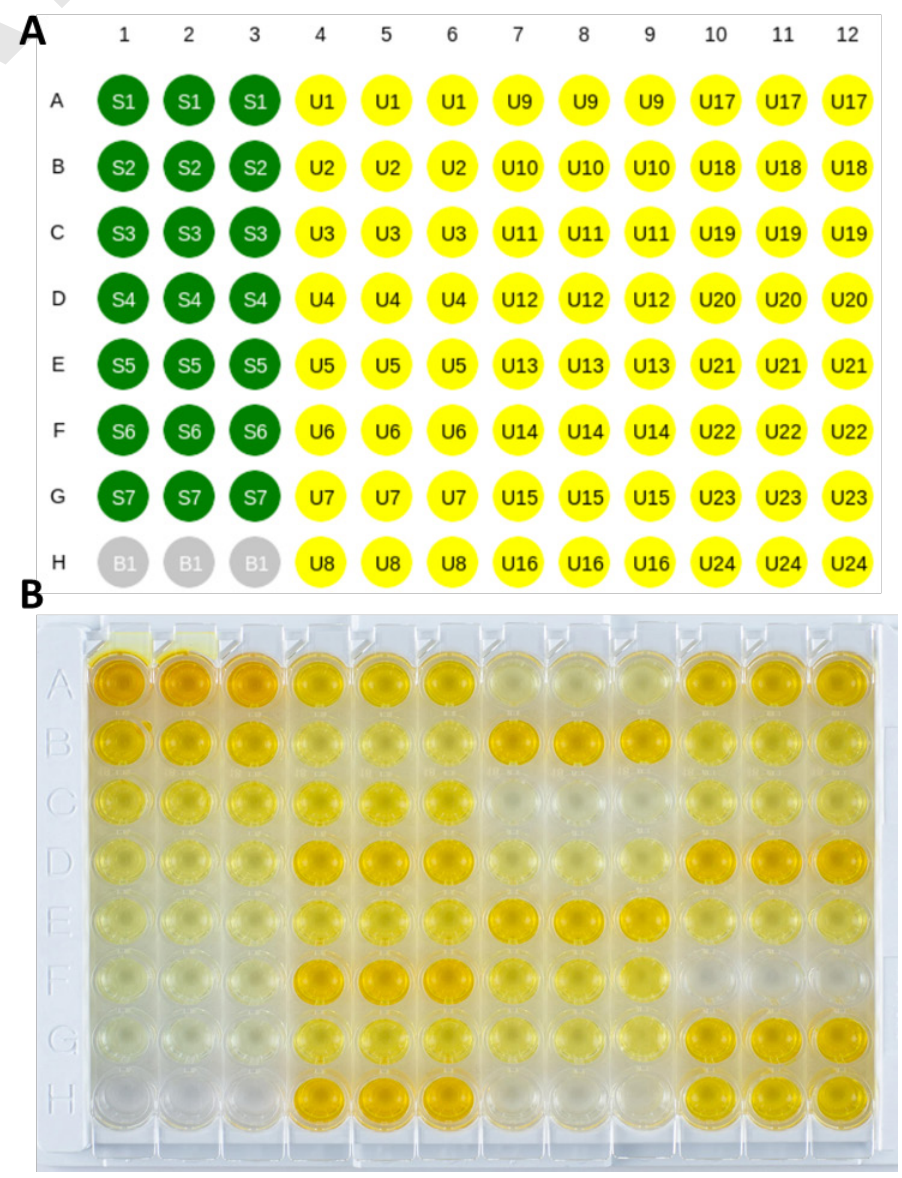


data and perform the calculations directly from the raw plate reader data (elisaanalysis.com).

\section{Enzyme Activity}

Unlike chemical and antibody assays, enzyme activity assays measure the activity of an enzyme, not just its concentration in a biological sample. Different isoforms of enzymes may vary in their rate of activity (Sulakhe \& Lautt, 1987), so it can be important to measure how much usefully active enzyme is present. Enzyme activity is the key biological process causing modifications to other proteins, such as cleaving or changing sugars, in essence controlling and regulating all key responses within an organism. The activity levels of certain enzymes are altered with changes in an animal's environment (e.g., quality of care or stress). In its simplest form, enzyme assays measure substrate cleavage; for example, amylase activity can be measured using the substrate blue starch. Amylase cleaves the sugar starch into smaller sugar molecules, releasing a blue dye that can then easily be measured. The amount of blue dye released is proportional to the amount of enzyme activity present within the sample (Abe et al., 1996).

However, as enzymes are an active biological molecule, their activity will change with temperature and the presence of certain chemicals. EDTA (ethylenediaminetetraacetic acid), a powerful chelating agent, sequesters ions such as calcium, iron, and zinc that are required by some enzymes for activity (Sabeur et al., 2001). So it is extremely important when designing enzyme assays to check that any buffer used for dilution is compatible with that enzyme assay.

\section{Polymerase Chain Reaction (PCR) Tests}

PCR tests amplify DNA from either a DNA or RNA template to aid in the identification of genes, mutations, or viral infection. These tests have a wide variety of uses, from identifying dogs that have mutations in the oxytocin receptor (OXTR) that can influence animal behaviour (Bence et al., 2017) to identifying species or breed types (Wu et al., 2018), and they can identify animals infected with a virus such as coronavirus (Chan et al., 2020). These PCR reactions take approximately $30 \mathrm{~min}$ to $3 \mathrm{hr}$ to run. The reagent cost per reaction is comparatively inexpensive (starting around $£ 0.30$ [US \$0.43]), but running the test requires a thermal cycler, which is a comparatively expensive piece of equipment.

RNA samples must be converted to DNA prior to PCR amplification, so an additional reverse transcrip- tase (RT) step is needed. This is important for identifying RNA-based viruses, such as those currently being used to detect COVID-19 infections in both humans and animals (Chan et al., 2020). The good news is that all-in-one RT-PCR kits are commercially available and can work from RNA in a single combined reaction step, but at a higher cost per sample.

\section{Proteomics}

Proteomics studies the variation in protein levels within a biological sample or even changes in the post-translational modification (PTM) status of proteins. Many factors increase/decrease protein levels to control processes in an organism, but at a cellular level, proteins can also be regulated once synthesised by PTM. For example, amino acid residues can undergo phosphorylation or acetylation within protein molecules. These PTMs can then alter the protein's behaviour - for example, changing its affinity for a target receptor, changing the proteins it binds, and even changing its half-life (speed of degradation). Most proteomic analysis is through western blotting analysis using specialised antibodies that are specific to certain proteins, isoform specific antibodies, and even antibodies that only bind and recognise proteins with certain PTMs on specific amino acid residues/sites. Proteomics has even been used to identify changes in PTM/phosphorylation at a global protein level in saliva samples of dogs infected from suspected tick-borne babesiosis (Galán et al., 2018).

\section{Mass Spectrometry}

Mass spectrometry identifies the presence and relative amounts of chemicals and proteins in a biological sample. Mass spectrometry accurately determines the exact molecular mass of the molecules present in biological samples, and these are then compared with known standards. An example of its use is an investigative study on dogs treated with cannabidiol for canine epilepsy that used a simple and fast gas-chromatography mass spectrometry assay to accurately quantify cannabidiol metabolite levels in serum samples (Rotolo et al., 2019). Mass spectrometry is usually provided as a service, either academically or commercially, because of both the high level of expertise required to undertake the analysis and the cost of the equipment. Mass spectrometry (LC-MS/MS) can be extremely useful in identifying PTMs on proteins and small molecules in biological samples that cannot easily be determined by antibody methodologies (Koivunen et al., 2006). 


\section{Factors That Might Influence Selection of Biomarkers}

Biological samples have a wide variety of influencing factors that are outside the researcher's control. Therefore, these factors might influence biomarker or sample selection (Figure 1) and can be summarised as follows:

- Length of time the marker might be present

- Half-life, excretion time, potential collection times (Wolff et al., 1999)

- Compounds that might affect readings

- Medications or contamination, for example lysed blood samples will have falsely high levels of lactate dehydrogenase (Solberg et al., 1986)

\section{- Medical conditions}

- For example, pancreatic disease can raise blood amylase levels, giving falsely high reading if using amylase is used as a marker of stress (Murtaugh \& Jacobs, 1985)

The use of biomarkers to evidence animal cognitive, welfare, and health issues has vastly influenced the ability of a researcher to accurately and easily quantify biomarkers and directly correlate these to observed behaviours. In conclusion, no one-size-fits-all solution exists for the analysis of biomarkers; rather, the selection of sample type and biomarker is dependent on the biological samples available and the ability to analyse the biomarkers. Care should be taken when deciding on the sample to ensure that the results will answer the research question. The correct assay needs to be chosen to give the precise, required information. Making the wrong choices here can lead to confusing results and incorrect conclusions, and we all know how bad science can be propagated.

After all, the old saying rings true: Garbage in equals garbage out.

\section{Biochemical Tips}

- Extraction of saliva from swaps: Saliva can be extracted and collected in Eppendorf microcentrifuge tubes by cutting the swab about $5 \mathrm{~mm}$ from the end of the swab and inverting it so that the stick is at the bottom of the tube. The tube can then be centrifuged briefly (about 4-6000 xg for 10-30 s) to pellet the saliva at the bottom of the tube for easy pipetting.

- Dilution of samples: Some samples (e.g., saliva samples) might have to be diluted (in our experience, this is common for the larger breeds of dogs), as the vis- cosity of the saliva can be too high to allow for pipetting and analysis. Commonly these dilutions are around 1:4 with the assay buffer.

- More is better: Although it adds to the costs, it is always better to carry out the analysis more than once, so run a single sample on an ELISA plate in duplicate or triplicate. That way, any single anomaly is removed, and the results are more reliable. No assay is perfect, so there will always be some built-in errors, and this helps to reduce them (but never removes them).

- Keep your samples appropriately: If the samples need to be at $4{ }^{\circ} \mathrm{C},-20{ }^{\circ} \mathrm{C}$, or $-80{ }^{\circ} \mathrm{C}$, keep them there, and avoid freeze thawing on multiple occasions where possible, as this can affect the results. Although this takes up space, the samples are there to go back to if needed and can even be used for other studies, such as testing for antibodies in a pandemic. But make sure that your ethical approval states this.

- Remember safety comes first: For example, collection of saliva swabs from rabid dogs is never a good idea, but from ordinary dogs it is fine. Faecal samples often hide hidden pathogens and dangers such as Salmonella, which is zoonotic and can make people very ill.

\section{References}

Aasland, K. E., Skjerve, E., \& Smith, A. J. (2010). Quality of blood samples from the saphenous vein compared with the tail vein during multiple blood sampling of mice. Laboratory Animals, 44(1), 25-29. https://doi. org/10.1258/la.2009.009017

Abe, K., Itoh, T., Tashiro, M., Okina, A., Gao, C., Nakamura, H., Nose, T., Inoue, H., \& Yu, S. F. (1996). The effects of 5-hydroxydopamine on salivary flow rates and protein secretion by the submandibular and parotid glands of rats. Experimental Physiology, 81(4), 645653. https://doi.org/10.1113/expphysiol.1996.sp003965

Accorsi, P. A., Carloni, E., Valsecchi, P., Viggiani, R., Gamberoni, M., Tamanini, C., \& Seren, E. (2008). Cortisol determination in hair and faeces from domestic cats and dogs. General and Comparative Endocrinology, 155(2), 398-402. https://doi. org/10.1016/j.ygcen.2007.07.002 
Alessio, L., Berlin, A., Dell'Orto, A., Toffoletto, F., \& Ghezzi, I. (1985). Reliability of urinary creatinine as a parameter used to adjust values of urinary biological indicators. International Archives of Occupational and Environmental Health, 55(2), 99-106. https://doi. org/10.1007/BF00378371

Allen, H. S., Steiner, J., Broussard, J., Mansfield, C., Williams, D. A., \& Jones, B. (2006). Serum and urine concentrations of trypsinogen-activation peptide as markers for acute pancreatitis in cats. Canadian Journal of Veterinary Research, 70(4), 313-316.

Ambrose, D. J., Radke, B., Pitney, P. A., \& Goonewardene, L. A. (2007). Evaluation of early conception factor lateral flow test to determine nonpregnancy in dairy cattle. The Canadian Veterinary Journal, 48(8), 831835.

Amaral, R. S. (2010). Use of alternative matrices to monitor steroid hormones in aquatic mammals: A review. Aquatic Mammals, 36(2), 162-171. https://doi. org/10.1578/AM.36.2.2010.162

Animal Science Procedure Act. (1986). http://www. legislation.gov.uk/ukpga/1986/14/contents.

Antwis, R. E., Edwards, K. L., Unwin, B., Walker, S. L., \& Shultz, S. (2019). Rare gut microbiota associated with breeding success, hormone metabolites and ovarian cycle phase in the critically endangered eastern black rhino. Microbiome, 7(1), Article 27. https://doi. org/10.1186/s40168-019-0639-0

Arola, L., Palou, A., Remesar, X., Herrera, E., \& Alemany, M. (1980). Effect of stress and sampling site on metabolite concentration in rat plasma. Archives Internationales de Physiologie et de Biochimie, 88(2), 99-105. https://doi.org/10.3109/13813458009075674

Athanasiou, L. V., Katsoulos, P. D., Katsogiannou, E. G., Polizopoulou, Z. S., Diamantaki, M., Kamatsos, C., \& Christodoulopoulos, G. (2018). Comparison between the urine dipstick and the $\mathrm{pH}$-meter to assess urine $\mathrm{pH}$ in sheep and dogs. Veterinary Clinical Pathology, 47(2), 284-288. https://doi.org/10.1111/vcp.12581

Beehner, J. C., \& Whitten, P. L. (2004). Modifications of a field method for fecal steroid analysis in baboons. Physiology \& Behavior, 82(2-3), 269-277. https://doi. org/10.1016/j.physbeh.2004.03.012
Bellomo, G., Sulas, M. G., Mairate, E., Bardone, M. B., \& Rolla, R. (2012). Hemolysis is a major cause of variability in insulin measurement during oral glucose tolerance test in children. Clinical Laboratory, 58(12), 67-74.

Bence, M., Marx, P., Szantai, E., Kubinyi, E., Ronai, Z., \& Banlaki, Z. (2017). Lessons from the canine Oxtr gene: populations, variants and functional aspects. Genes, Brain, and Behavior, 16(4), 427-438. https:// doi.org/10.1111/gbb.12356

Bennett,A., \& Hayssen, V. (2010). Measuring cortisol in hair and saliva from dogs: coat color and pigment differences. Domestic Animal Endocrinology, 39(3), 171-180. https://doi.org/10.1016/j.domaniend.2010.04.003

Bielohuby, M., Popp, S., \& Bidlingmaier, M. (2012). A guide for measurement of circulating metabolic hormones in rodents: Pitfalls during the pre-analytical phase. Molecular Metabolism, 1(1-2), 47-60. https:// doi.org/10.1016/j.molmet.2012.07.004

Boag, A. M., Breheny, C., Handel, I., \& Gow, A. G. (2019). Evaluation of the effect of urine dip vs urine drip on multi-test strip results. Veterinary Clinical Pathology, 48(2), 276-281. https://doi.org/10.1111/vcp.12730

Bowen, R. A., Hortin, G. L., Csako, G., Otañez, O. H., \& Remaley, A. T. (2010). Impact of blood collection devices on clinical chemistry assays. Clinical Biochemistry, 43(1-2), 4-25. https://doi.org/10.1016/j. clinbiochem.2009.10.001

Bouatra, S., Aziat, F., Mandal, R., Guo, A. C., Wilson, M. R., Knox, C., Bjorndahl, T. C., Krishnamurthy, R., Saleem, F., Liu, P., Dame, Z. T., Poelzer, J., Huynh, J., Yallou, F. S., Psychogios, N., Dong, E., Bogumil, R., Roehring, C., \& Wishart, D. S. (2013). The human urine metabolome. PLOS ONE, 8(9), e73076. https://doi. org/10.1371/journal.pone.0073076

Carlitz, E. H., Kirschbaum, C., Miller, R., Rukundo, J., \& van Schaik, C. P. (2015). Effects of body region and time on hair cortisol concentrations in chimpanzees (Pan troglodytes). General and Comparative Endocrinology, 223, 9-15. https://doi.org/10.1016/j.ygcen.2015.09.022 
Carrieri, M., Trevisan, A., \& Bartolucci, G. B. (2000). Adjustment to concentration-dilution of spot urine samples: correlation between specific gravity and creatinine. International Archives of Occupational and Environmental Health, 74(1), 63-67. https://doi. org/10.1007/s004200000190

Chan, J. F., Yip, C. C., To, K. K., Tang, T. H., Wong, S. C., Leung, K. H., Fung, A. Y., Ng, A. C., Zou, Z., Tsoi, H. W., Choi, G. K., Tam, A. R., Cheng, V. C., Chan, K. H., Tsang, O. T., \& Yuen, K. Y. (2020). Improved Molecular Diagnosis of COVID-19 by the Novel, Highly Sensitive and Specific COVID-19-RdRp/Hel Real-Time Reverse Transcription-PCR Assay Validated In Vitro and with Clinical Specimens. Journal of Clinical Microbiology, 58(5), e00310-20. https://doi.org/10.1128/JCM.0031020

Chard T. (1992). Pregnancy tests: a review. Human Reproduction (Oxford, England), 7(5), 701-710. https:// doi.org/10.1093/oxfordjournals.humrep.a137722

Cell Signaling Technology. (n.d.). Types of ELISA (Enzyme-linked Immunosorbent Assay) Tests. https:// www.cellsignal.co.uk/applications/elisa/types-of-elisatests

Chen, Z., Li, J., Zhang, J., Xing, X., Gao, W., Lu, Z., \& Deng, H. (2013). Simultaneous determination of hair cortisol, cortisone and DHEAS with liquid chromatographyelectrospray ionization-tandem mass spectrometry in negative mode. Journal of Chromatography. B, Analytical Technologies in the Biomedical and Life Sciences, 929, 187-194. https://doi.org/10.1016/j. jchromb.2013.04.026

Choi, S., Kim, S., Yang, J. S., Lee, J. H., Joo C, \& Jung, H. I. (2014) Real-time measurement of human salivary cortisol for the assessment of psychological stress using a smartphone. Sensing and Bio-Sensing Research. 2(0):8-11. https://doi.org/10.1016/j.sbsr.2014.08.001

Christensen, S. D., Mikkelsen, L. F., Fels, J. J., Bodvarsdóttir, T. B., \& Hansen, A. K. (2009). Quality of plasma sampled by different methods for multiple blood sampling in mice. Laboratory Animals, 43(1), 65-71. https://doi.org/10.1258/1a.2008.007075
Cizauskas, C. A., Turner, W. C., Pitts, N., \& Getz, W. M. (2015). Seasonal patterns of hormones, macroparasites, and microparasites in wild African ungulates: the interplay among stress, reproduction, and disease. PLOS ONE, 10(4), e0120800. https://doi.org/10.1371/ journal.pone. 0120800

Cobb, M. L., Iskandarani, K., Chinchilli, V. M., \& Dreschel, N. A. (2016). A systematic review and metaanalysis of salivary cortisol measurement in domestic canines. Domestic Animal Endocrinology, 57, 31-42. https://doi.org/10.1016/j.domaniend.2016.04.003

Colussi, A., Stefanon, B., Adorini, C. \& Sandri, M. (2018) Variations of salivary cortisol in dogs exposed to different cognitive and physical activities, Italian Journal of Animal Science, 17(4), 1030-1037. https:// doi.org/10.1080/1828051X.2018.1453756

Cook, N. J., Hayne, M. S., Rioja-Lang, F. C., Schaefer, A. L., \& Gonyou, H. W. (2013) The collection of multiple saliva samples from pigs and the effect on adrenocortical activity. Canadian Journal of Animal Science, 93, 329333. https://doi.org/10.4141/cjas2012-120

Dabbs J. M., Jr(1991). Salivary testosterone measurements: collecting, storing, and mailing saliva samples. Physiology \& Behavior, 49(4), 815-817. https://doi. org/10.1016/0031-9384(91)90323-g

Danish, L. M., Heistermann, M., Agil, M., \& Engelhardt, A. (2015). Validation of a Novel Collection Device for Non-Invasive Urine Sampling from Free-Ranging Animals. PLOS ONE, 10(11), e0142051. https://doi. org/10.1371/journal.pone.0142051

Davis, N., Schaffner, C. M., Smith, T. E., (2005). Evidence that zoo visitors influence HPA activity in spider monkeys (Ateles geoffroyii rufiventris). Applied Animal Behavior Science, 90, 131-141. https://doi. org/10.1016/j.applanim.2004.08.020

Dickerson, S. S., \& Kemeny, M. E. (2004). Acute stressors and cortisol responses: a theoretical integration and synthesis of laboratory research. Psychological Bulletin, 130(3), 355-391. https://doi.org/10.1037/00332909.130.3.355

Dolph, C. I., Braun, H. A., \& Pfeiffer, E. W. (1962). The Effect of Vasopressin upon Urine Concentration in Aplodontia rufa (Sewellel) and the Rabbit. Physiological Zoology, 35, 263-269. https://doi.org/10.1086/ physzool.35.3.30152811 
Dorward, D. W., Schwan, T. G., \& Garon, C. F. (1991). Immune capture and detection of Borrelia burgdorferi antigens in urine, blood, or tissues from infected ticks, mice, dogs, and humans. Journal of Clinical Microbiology, 29(6), 1162-1170. https://doi. org/10.1128/JCM.29.6.1162-1170.1991

Dzviti, M., Mapfumo, L., \& Muchenje, V. (2019). Relationship between saliva and blood cortisol in handled cows. Asian-Australasian Journal of Animal Sciences, 32(5), 734-741. https://doi.org/10.5713/ ajas. 18.0151

El-Bahr, S. M., Kahlbacher, H., Rausch, W. D., \& Palme, R. G. (2005) Excretion of CA (adrenaline and noradrenaline) in domestic livestock. Veterinary Medicine Austria / Wiener Tierarztliche Monatsschrift, 92, 207-213

ELISA Analysis. https://elisaanalysis.com/app

Elmér, M., \& Ohlin, P. (1971). Salivary secretion in the rat in a hot environment. Acta Physiologica Scandinavica, 83(2), 174-178. https://doi. org/10.1111/j.1748-1716.1971.tb05067.x

Emery Thompson, M., Muller, M. N., \& Wrangham, R. W. (2012). Technical note: variation in muscle mass in wild chimpanzees: application of a modified urinary creatinine method. American Journal of Physical Anthropology, 149(4), 622-627. https://doi. org/10.1002/ajpa.22157

Fell, L. R., Shutt, D. A., \& Bentley, C. J. (1985). Development of a salivary cortisol method for detecting changes in plasma "free" cortisol arising from acute stress in sheep. Australian Veterinary Journal, 62(12), 403-406. https://doi.org/10.1111/j.1751-0813.1985. tb14120.x

Ferrero, D. M., \& Liberles, S. D. (2010). The secret codes of mammalian scents. Wiley interdisciplinary reviews. Systems Biology and Medicine, 2(1), 23-33. https://doi. org/10.1002/wsbm.39

Fitzner Toft, M., Petersen, M. H., Dragsted, N., \& Hansen, A. K. (2006). The impact of different blood sampling methods on laboratory rats under different types of anaesthesia. Laboratory Animals, 40(3), 261-274. https://doi.org/10.1258/002367706777611433
Galán, A., Horvatić, A., Kuleš, J., Bilić, P., Gotić, J., \& Mrljak, V. (2018). LC-MS/MS analysis of the dog serum phosphoproteome reveals novel and conserved phosphorylation sites: Phosphoprotein patterns in babesiosis caused by Babesia canis, a case study. PLOS ONE, 13(11), e0207245. https://doi.org/10.1371/ journal.pone.

Gao, W., Kirschbaum, C., Grass, J., \& Stalder, T. (2016). LC-MS based analysis of endogenous steroid hormones in human hair. The Journal of Steroid Biochemistry and Molecular Biology, 162, 92-99. https://doi. org/10.1016/j.jsbmb.2015.12.022

Gao, W., Stalder, T., Foley, P., Rauh, M., Deng, H., \& Kirschbaum, C. (2013). Quantitative analysis of steroid hormones in human hair using a column-switching LC-APCI-MS/MS assay. Journal of Chromatography. $B$, Analytical Technologies in the Biomedical and Life Sciences, 928, 1-8. https://doi.org/10.1016/j. jchromb.2013.03.008

Garnier, J. N., Green, D. I., Pickard, A. R., Shaw, H. J., \& Holt, W. V. (1998). Non-invasive diagnosis of pregnancy in wild black rhinoceros (Diceros bicornis minor) by faecal steroid analysis. Reproduction, Fertility, and Development, 10(6), 451-458. https://doi.org/10.1071/ RD98118

Goff, J. P., Littledike, E. T., \& Horst, R. L. (1986). Effect of synthetic bovine parathyroid hormone in dairy cows: prevention of hypocalcemic parturient paresis. Journal of Dairy Science, 69(9), 2278-2289. https:// doi.org/10.3168/jds.S0022-0302(86)80666-X

Gordon, C. R., \& Lavie, P. (1985). Day-night variations in urine excretions and hormones in dogs: role of autonomic innervation. Physiology \& Behavior, 35(2), 175-181. https://doi.org/10.1016/0031-9384(85)90332-4

Goymann W. (2005). Noninvasive monitoring of hormones in bird droppings: physiological validation, sampling, extraction, sex differences, and the influence of diet on hormone metabolite levels. Annals of the New York Academy of Sciences, 1046, 35-53. https://doi. org/10.1196/annals.1343.005

Goymann, W. (2012). On the use of non-invasive hormone research in uncontrolled, natural environments: the problem with sex, diet, metabolic rate and the individual. Methods in Ecology and Evolution, 3, 757-765. https:// doi.org/10.1111/j.2041-210X.2012.00203.x 
Goymann, W., Mostl, E., \& Gwinner, E. (2002). Corticosterone metabolites can be measured noninvasively in excreta of European stonechats (Saxicola torquata rubicola). The Auk, 119, 1167-1173. https://doi.org/10.1642/0004-8038(2002)119[1167:CM CBMN]2.0.CO;2

Granger, D. A., Schwartz, E. B., Booth, A., \& Arentz, M. (1999). Salivary testosterone determination in studies of child health and development. Hormones and Behavior, 35(1), 18-27. https://doi.org/10.1006/hbeh.1998.1492

Grant, J. K., \& Beastall, G. H. (1983). Clinical biochemistry of steroid hormones: Methods and applications. Elsevier Science.

Grass, J., Miller, R., Carlitz, E. H., Patrovsky, F., Gao, W., Kirschbaum, C., \& Stalder, T. (2016). In vitro influence of light radiation on hair steroid concentrations. Psychoneuroendocrinology, 73, 109-116. https://doi. org/10.1016/j.psyneuen.2016.07.221

Greenwood, P. L., \& Shutt, D. A. (1992). Salivary and plasma cortisol as an index of stress in goats. Australian Veterinary Journal, 69(7), 161-163. https://doi. org/10.1111/j.1751-0813.1992.tb07501.x

Greig D. J., Mashburn, K. L., Rutishauser, M., Gulland, F. M. D., Williams, T. M., \& Atkinson, S. (2007) Seasonal changes in circulating progesterone and estrogen concentrations in the California Sea Lion (Zalophus californianus), Journal of Mammalogy, 88, 67-72. https://doi.org/10.1644/06-MAMM-A-060R2.1

Gröschl, M., Wagner, R., Rauh, M., \& Dörr, H. G. (2001). Stability of salivary steroids: The influences of storage, food and dental care. Steroids, 66(10), 737-741. https:// doi.org/10.1016/s0039-128x(01)00111-8

Gunnar, M. R., \& Vazquez, D. (2006) Stress neurobiology and developmental psychopathology. In D. Cicchetti \& D. J. Cohen (Eds.), Developmental psychopathology. 2nd ed. (Vol. 2, pp. 533-577). Wiley \& Sons. https:// doi.org/10.1002/9780470939390.ch13

Gutiérrez, J., Gazzano, A., Torracca, B., Meucci, V., \& Mariti, C. (2019). Determination of Prolactin in Canine Saliva: Is it Possible to Use a Commercial ELISA kit? Animals: An Open Access Journal from MDPI, 9(7), Article 418. https://doi.org/10.3390/ani9070418
Hadinger, U., Haymerle, A., Knauer, F., Schwarzenberger, F., \& Walzer, C. (2015). Faecal cortisol metabolites to assess stress in wildlife: Evaluation of a field method in free-ranging chamois. Methods in Ecology and Evolution, 6(11), 1349-1357. https://doi. org/10.1111/2041-210X.12422

Harper, J. M., \&Austad, S. N. (2000). Fecal glucocorticoids: A noninvasive method of measuring adrenal activity in wild and captive rodents. Physiological and Biochemical Zoology: PBZ, 73(1), 12-22. https://doi. org/10.1086/316721

Hay, A. D., Birnie, K., Busby, J., Delaney, B., Downing, H., Dudley, J., Durbaba, S., Fletcher, M., Harman, K., Hollingworth, W., Hood, K., Howe, R., Lawton, M., Lisles, C., Little, P., MacGowan, A., O’Brien, K., Pickles, T., Rumsby, K., ... Butler, C. C. (2016). The Diagnosis of Urinary Tract infection in Young children (DUTY): A diagnostic prospective observational study to derive and validate a clinical algorithm for the diagnosis of urinary tract infection in children presenting to primary care with an acute illness. Health Technology Assessment (Winchester, England), 20(51), 1-294. https://doi.org/10.3310/

Heimbürge, S., Kanitz, E., \& Otten, W. (2019). The use of hair cortisol for the assessment of stress in animals. General and Comparative Endocrinology, 270, 10-17. https://doi.org/10.1016/j.ygcen.2018.09.016

Heistermann, M. (2010). Non-invasive monitoring of endocrine status in laboratory primates: methods, guidelines and applications. Advances in Science and Research, 5. https://doi.org/10.5194/asr-5-1-2010

Hernandez, S. E., Strona, A., Leiner, N. O., Suzán, G., \& Romano, M. C. (2018). Seasonal changes of faecal cortisol metabolite levels in Gracilinanus agilis (Didelphimorphia: Didelphidae) and its association to life histories variables and parasite loads. Conservation Physiology, 6(1), coy021. https://doi.org/10.1093/ conphys/coy021

Hess, R. S., Saunders, H. M., Van Winkle, T. J., \& Ward, C. R. (2000). Concurrent disorders in dogs with diabetes mellitus: 221 cases (1993-1998). Journal of the American Veterinary Medical Association, 217(8), 1166-1173. https://doi.org/10.2460/javma.2000.217.1166 
Higham, J. P., Vitale, A. B., Rivera, A. M., Ayala, J. E., \& Maestripieri, D. (2010). Measuring salivary analytes from free-ranging monkeys. Physiology \& Behavior, 101(5), 601-607. https://doi.org/10.1016/j. physbeh.2010.09.003

Hodges, J. K., \& Heistermann, M. (2011). Field endocrinology: monitoring hormonal changes in freeranging primates. In J. M. Setchell \& D. J. Curtis (Eds.), Field and laboratory methods in primatology. A practical guide (pp. 353-370). Cambridge University Press. https://doi.org/10.1017/CBO9780511921643.022

Hong, H. R., Oh, Y. I., Kim, Y. J., \& Seo, K. W. (2019). Salivary alpha-amylase as a stress biomarker in diseased dogs. Journal of Veterinary Science, 20(5), e46. https:// doi.org/10.4142/jvs.2019.20.e46

Hooda, S., Vester Boler, B. M., Kerr, K. R., Dowd, S. E., \& Swanson, K. S. (2013). The gut microbiome of kittens is affected by dietary protein:carbohydrate ratio and associated with blood metabolite and hormone concentrations. The British Journal of Nutrition, 109(9), 1637-1646. https://doi.org/10.1017/ S0007114512003479

Isobe, N., Akita, M., Nakao, T., Yamashiro, H., \& Kubota, H. (2005). Pregnancy diagnosis based on the fecal progesterone concentration in beef and dairy heifers and beef cows. Animal Reproduction Science, 90(3-4), 211218. https://doi.org/10.1016/j.anireprosci.2005.02.004

Ito, K., Morikawa, M., \& Inenaga, K. (2001). The effect of food consistency and dehydration on reflex parotid and submandibular salivary secretion in conscious rats. Archives of Oral Biology, 46(4), 353-363. https://doi. org/10.1016/s0003-9969(00)00124-2

Jacques, K., Harmon, D. L., Croom, W. J., Jr., \& Hagler, W. M., Jr (1989). Estimating salivary flow and ruminal water balance of intake, diet, feeding pattern, and slaframine. Journal of Dairy Science, 72(2), 443-452. https://doi.org/10.3168/jds.S0022-0302(89)79126-8

Kalbitzer, U., \& Heistermann, M. (2013). Long-term storage effects in steroid metabolite extracts from baboon (Papio sp.) faeces-A comparison of three commonly applied storage methods. Methods in Ecology and Evolution, 4, 493-500. https://doi.org/10.1111/2041210X.12054
Kalliokoski, O., Jellestad, F. K., \& Murison, R. (2019). A systematic review of studies utilizing hair glucocorticoids as a measure of stress suggests the marker is more appropriate for quantifying short-term stressors. Scientific Reports, 9(1), 11997. https://doi. org/10.1038/s41598-019-48517-2

Kapoor, A., Lubach, G., Hedman, C., Ziegler, T. E., \& Coe, C. L. (2014). Hormones in infant rhesus monkeys' (Macaca mulatta) hair at birth provide a window into the fetal environment. Pediatric Research, 75(4), 476481. https://doi.org/10.1038/pr.2014.1

Kaushik, A., Vasudev, A., Arya, S. K., Pasha, S. K., \& Bhansali, S. (2014). Recent advances in cortisol sensing technologies for point-of-care application. Biosensors \& Bioelectronics, 53, 499-512. https://doi.org/10.1016/j. bios.2013.09.060

Keckeis, K., Lepschy, M., Schöpper, H., Moser, L., Troxler, J., \& Palme, R. (2012). Hair cortisol: A parameter of chronic stress? Insights from a radiometabolism study in guinea pigs. Journal of Comparative Physiology. B, Biochemical, Systemic, and Environmental Physiology, 182(7), 985-996. https://doi.org/10.1007/s00360-0120674-7

Kirschbaum, C., Pirke, K. M., \& Hellhammer, D. H. (1993). The 'Trier Social Stress Test'--a tool for investigating psychobiological stress responses in a laboratory setting. Neuropsychobiology,28(1-2), 7681. https://doi.org/10.1159/000119004

Knott, C. D. (1997) Field collection and preservation of urine in orangutans and chimpanzees. Tropical Biodiversity, 4(1), 95-102.

Koivunen, M. E., Dettmer, K., Vermeulen, R., Bakke, B., Gee, S. J., \& Hammock, B. D. (2006). Improved methods for urinary atrazine mercapturate analysis--assessment of an enzyme-linked immunosorbent assay (ELISA) and a novel liquid chromatography-mass spectrometry (LC-MS) method utilizing online solid phase extraction (SPE). Analytica Chimica Acta, 572(2), 180-189. https://doi.org/10.1016/j.aca.2006.05.037

Kolevská, J., V. Brunclík, M., \& Svoboda (2003) Circadian rhythm of cortisol secretion in dogs of different daily activities. Acta Veterinaria Brno, 72, 599-605. https:// doi.org/10.2754/avb200372040599 
Kontny, N. E., Hempel, G., Boos, J., Boddy, A. V., \& Krischke, M. (2011). Minimization of the preanalytical error in plasma samples for pharmacokinetic analyses and therapeutic drug monitoring-Using doxorubicin as an example. Therapeutic Drug Monitoring, 33(6), 766771. https://doi.org/10.1097/FTD.0b013e31823aa8ab

Koren, L., Bryan, H., Matas, D., Tinman, S., Fahlman, A., Whiteside, D., Smits, J., \& Wynne-Edwards, K. (2019). Towards the validation of endogenous steroid testing in wildlife hair. Journal of Applied Ecology, 56, 547-561. https://doi.org/10.1111/1365-2664.13306

Koseoglu, M., Hur, A., Atay, A., \& Cuhadar, S. (2011). Effects of hemolysis interferences on routine biochemistry parameters. Biochemia Medica, 21(1), 79-85. https://doi.org/10.11613/bm.2011.015

Kurien, B. T., Everds, N. E., \& Scofield, R. H. (2004). Experimental animal urine collection: a review. Laboratory Animals, 38(4), 333-361. https://doi. org/10.1258/0023677041958945

Kutsukake, N., Ikeda, K., Honma, S., Teramoto, M., Mori, Y., Hayasaka, I., Yamamoto, R., Ishida, T., Yoshikawa, Y., \& Hasegawa, T. (2009). Validation of salivary cortisol and testosterone assays in chimpanzees by liquid chromatography-tandem mass spectrometry. American Journal of Primatology, 71(8), 696-706. https://doi.org/10.1002/ajp.20708

Lane, M. B., Flatland, B., Olin, S. J., Fecteau, K. A., Rick, M., \& Giori, L. (2018). Analytic performance evaluation of a veterinary-specific ELISA for measurement of serum cortisol concentrations of dogs. Journal of the American Veterinary Medical Association, 253(12), 1580-1588. https://doi.org/10.2460/javma.253.12.1580

Laudenslager, M. L., Bettinger, T., \& Sackett, G. P. (2006) Saliva as a medium for assessing cortisol and other compounds in nonhuman primates: collection, assay, and examples. In G. P. Sackett, G. C. Ruppentahal, \& $\mathrm{K}$. Elias (Eds.), Nursery rearing of nonhuman primates in the 21st century (pp. 403-427). Springer. https://doi. org/10.1007/978-0-387-25640-5_20

Laule, G. E., Thurston, R. H., Alford, P. L. and Bloomsmith, M. A., (1996). Training to reliably obtain blood and urine samples from a diabetic chimpanzee (Pan troglodytes). Zoo Biology, 15(6), 587-591. https://doi. org/10.1002/(SICI)1098-2361(1996)15:6<587::AID$\mathrm{ZOO} 4>3.0 . \mathrm{CO} ; 2-7$
Lepschy, M., Touma, C., Hruby, R., \& Palme, R. (2007). Non-invasive measurement of adrenocortical activity in male and female rats. Laboratory Animals, 41(3), 372387. https://doi.org/10.1258/002367707781282730

Lippi, G., Franchini, M., Montagnana, M., Salvagno, G. L., Poli, G., \& Guidi, G. C. (2006). Quality and reliability of routine coagulation testing: can we trust that sample? Blood Coagulation \& Fibrinolysis, 17(7), 513-519. https://doi.org/10.1097/01.mbc.0000245290.57021.46

Lippi, G., Salvagno, G. L., Montagnana, M., Brocco, G., \& Guidi, G. C. (2006b). Influence of hemolysis on routine clinical chemistry testing. Clinical Chemistry and Laboratory Medicine, 44(3), 311-316. https://doi. org/10.1515/CCLM.2006.054

Lombardi, G., Lanteri, P., Colombini, A., \& Banfi, G. (2012). Blood biochemical markers of bone turnover: pre-analytical and technical aspects of sample collection and handling. Clinical Chemistry and Laboratory Medicine, 50(5), 771-789. https://doi.org/10.1515/ cclm-2011-0614

Mack, Z., \& Fokidis, H. B. (2017). A novel method for assessing chronic cortisol concentrations in dogs using the nail as a source. Domestic Animal Endocrinology, 59, 53-57. https://doi.org/10.1016/j. domaniend.2016.11.003

MacLean, E. L., Gesquiere, L. R., Gee, N., Levy, K., Martin, W. L., \& Carter, C. S. (2018). Validation of salivary oxytocin and vasopressin as biomarkers in domestic dogs. Journal of Neuroscience Methods, 293, 67-76. https://doi.org/10.1016/j.jneumeth.2017.08.033

Magnano, C. L., Diamond, E. J., \& Gardner, J. M. (1989). Use of salivary cortisol measurements in young infants: A note of caution. Child Development, 60(5), 10991101. https://doi.org/10.2307/1130784

Maia, O. B., Jácomo, A. T., Bringel, B. A., Kashivakura, C. K., Oliveira, C. A., Teodoro, L. O., Silveira, L., Teixeira da Costa, M. E., Malta, M. C., Furtado, M. M., Torres, N. M., Mattos, P. S., Viau, P., Lima, T. F., \& Morato, R. G. (2008). Comparison of serum hormone levels of captive and free-living maned wolves Chrysocyon brachyurus. Brazilian Journal of Medical and Biological Research, 41(2), 176-179. https://doi. org/10.1590/s0100-879x2008000200015 
Matas, D., Keren-Rotem, T., \& Koren, L. (2016). A method to determine integrated steroid levels in wildlife claws. General and Comparative Endocrinology, 230231,26-28.https://doi.org/10.1016/j.ygcen.2016.03.020

McLean, L., Hurst, J. L., Gaskell, C. J., Lewis, J. C., \& Beynon, R. J. (2007). Characterization of cauxin in the urine of domestic and big cats. Journal of Chemical Ecology, 33(10), 1997-2009. https://doi.org/10.1007/ s10886-007-9354-6

Mesarcova L., Kottferova J., Skurkova L., Leskova L., Kmecova N. (2017). Analysis of cortisol in dog hair a potential biomarker of chronic stress: A review. Veterinarni Medicina, 62, 363 -376. https://doi. org/10.17221/19/2017-VETMED

Miller, R. C., Brindle, E., Holman, D. J., Shofer, J., Klein, N. A., Soules, M. R., \& O'Connor, K. A. (2004). Comparison of specific gravity and creatinine for normalizing urinary reproductive hormone concentrations. Clinical Chemistry, 50(5), 924-932. https://doi.org/10.1373/clinchem.2004.032292

Millspaugh, J. J., \& Washburn, B. E. (2004). Use of fecal glucocorticoid metabolite measures in conservation biology research: considerations for application and interpretation. General and Comparative Endocrinology, 138(3), 189-199. https://doi. org/10.1016/j.ygcen.2004.07.002

Mitsui, S., Yamamoto, M., Nagasawa, M., Mogi, K., Kikusui, T., Ohtani, N., \& Ohta, M. (2011). Urinary oxytocin as a noninvasive biomarker of positive emotion in dogs. Hormones and Behavior, 60(3), 239243. https://doi.org/10.1016/j.yhbeh.2011.05.012

Mormède, P., Andanson, S., Aupérin, B., Beerda, B., Guémené, D., Malmkvist, J., Manteca, X., Manteuffel, G., Prunet, P., van Reenen, C. G., Richard, S., \& Veissier, I. (2007). Exploration of the hypothalamicpituitary-adrenal function as a tool to evaluate animal welfare. Physiology \& Behavior, 92(3), 317-339. https://doi.org/10.1016/j.physbeh.2006.12.003

Muller, M. N., \& Lipson, S. F. (2003). Diurnal patterns of urinary steroid excretion in wild chimpanzees. American Journal of Primatology, 60(4), 161-166. https://doi. org/10.1002/ajp.10103
Muneta, Y., Yoshikawa, T., Minagawa, Y., Shibahara, T., Maeda, R., \& Omata, Y. (2010). Salivary IgA as a useful non-invasive marker for restraint stress in pigs. The Journal of Veterinary Medical Science, 72(10), 12951300. https://doi.org/10.1292/jvms.10-0009

Murtaugh, R. J., \& Jacobs, R. M. (1985). Serum amylase and isoamylases and their origins in healthy dogs and dogs with experimentally induced acute pancreatitis. American Journal of Veterinary Research, 46(3), 742-747.

Musshoff,F., \& Madea,B.(2007). New trends in hairanalysis and scientific demands on validation and technical notes. Forensic Science International, 165(2-3), 204215. https://doi.org/10.1016/j.forsciint.2006.05.024

Nagasawa, M., Kikusui, T., Onaka, T., \& Ohta, M. (2009). Dog's gaze at its owner increases owner's urinary oxytocin during social interaction. Hormones and Behavior, 55(3), 434-441. https://doi.org/10.1016/j. yhbeh.2008.12.002

Nara, S., Tripathi, V., Singh, H., \& Shrivastav, T. G. (2010). Colloidal gold probe based rapid immunochromatographic strip assay for cortisol. Analytica Chimica Acta, 682(1-2), 66-71. https://doi.org/10.1016/j.aca.2010.09.041

Negrão, J. A., Porcionato, M. A., de Passillé, A. M., \& Rushen, J. (2004). Cortisol in saliva and plasma of cattle after ACTH administration and milking. Journal of Dairy Science, 87(6), 1713-1718. https://doi. org/10.3168/jds.S0022-0302(04)73324-X

Nemeth, M., Pschernig, E., Wallner, B., \& Millesi, E. (2016). Non-invasive cortisol measurements as indicators of physiological stress responses in guinea pigs. PeerJ, 4, e1590. https://doi.org/10.7717/peerj. 1590

Palme, R. (2005). Measuring fecal steroids: guidelines for practical application. Annals of the New York Academy of Sciences, 1046, 75-80. https://doi.org/10.1196/ annals. 1343.007

Palme, R. (2019). Non-invasive measurement of glucocorticoids: Advances and problems. Physiology \& Behavior, 199, 229-243. https://doi.org/10.1016/j. physbeh.2018.11.021 
Peter, I. D., Haron, A. W., Jesse, F., Ajat, M., Han, M., Fitri, W. N., Yahaya, M. S., \& Alamaary, M. (2018). Opportunities and challenges associated with fecal progesterone metabolite analysis. Veterinary World, 11(10), 1466-1472. https://doi.org/10.14202/ vetworld.2018.1466-1472

Polonsky, K. S., Pugh, W., Jaspan, J. B., Cohen, D. M., Karrison, T., Tager, H. S., \& Rubenstein, A. H. (1984). $\mathrm{C}$-peptide and insulin secretion. Relationship between peripheral concentrations of C-peptide and insulin and their secretion rates in the dog. The Journal of Clinical Investigation, 74(5), 1821-1829. https://doi. org/10.1172/JCI111601

Ravnik, U., Bajuk, B. P., Lusa, L., \& Tozon, N. (2014). Serum protein profiles, circulating immune complexes and proteinuria in dogs naturally infected with Anaplasma phagocytophilum. Veterinary Microbiology, 173(1-2), 160-165. https://doi.org/10.1016/j.vetmic.2014.07.007

Read, G. F., Walker, R. F., Wilson, D. W., \& Griffiths, K. (1990). Steroid analysis in saliva for the assessment of endocrine function. Annals of the New York Academy of Sciences, 595, 260-274. https://doi. org/10.1111/j.1749-6632.1990.tb34300.x

Reimers, T. J., McCann, J. P., \& Cowan, R. G. (1983). Effects of storage times and temperatures on T3, T4, $\mathrm{LH}$, prolactin, insulin, cortisol and progesterone concentrations in blood samples from cows. Journal of Animal Science, 57(3), 683-691. https://doi. org/10.2527/jas1983.573683x

Riad-Fahmy, D., Read, G. F., Walker, R. F., \& Griffiths, K. (1982). Steroids in saliva for assessing endocrine function. Endocrine Reviews, 3(4), 367-395. https:// doi.org/10.1210/edry-3-4-367

Romero, L. M., \& Reed, J. M. (2005). Collecting baseline corticosterone samples in the field: is under $3 \mathrm{~min}$ good enough? Comparative Biochemistry and Physiology. Part A, Molecular \& Integrative Physiology, 140(1), 73-79. https://doi.org/10.1016/j.cbpb.2004.11.004

Rotolo, M. C., Graziano, S., Pellegrini, M., Corlazzoli, D., Antinori, L., Porcarelli, L., \& Pichini, S. (2017). Simple and Fast gas-chromatography mass spectrometry assay to assess delta 9-tetrahydrocannabinol and cannabidiol in dogs treated with medical cannabis for canine epilepsy. Current Pharmaceutical Biotechnology, 18(10), 821-827. https://doi.org/10.217 4/1389201018666171122115815
Sabeur, K., Vo, A. T., \& Ball, B. A. (2001). Characterization of angiotensin-converting enzyme in canine testis. Reproduction (Cambridge, England), 122(1), 139-146. https://doi.org/10.1530/rep.0.1220139

Schönning, C., Leeming, R., \& Stenström, T. A. (2002). Faecal contamination of source-separated human urine based on the content of faecal sterols. Water Research, 36(8), 1965-1972. https://doi.org/10.1016/ s0043-1354(01)00427-4

Schwarzenberger, F., Möstl, E., Palme, R. \& Bamberg, E., (1996). Faecal steroid analysis for non-invasive monitor\& of reproductive status in farm, wild and zoo animals. Animal Reproduction Science, 42(5), pp.15526. https://doi.org/10.1016/0378-4320(96)01561-8

Schweikert, H. U., \& Wilson, J. D. (1974). Regulation of human hair growth by steroid hormones. I. Testosterone metabolism in isolated hairs. The Journal of Clinical Endocrinology \& Metabolism, 38(5), pp.811-819. https://doi.org/10.1210/jcem-38-5-811

Sheriff, M. J., Dantzer, B., Delehanty, B., Palme, R., \& Boonstra, R. (2011). Measuring stress in wildlife: techniques for quantifying glucocorticoids. Oecologia, 166(4), 869-887. https://doi.org/10.1007/s00442011-1943-y

Shirtcliff, E. A., Buck, R. L., Laughlin, M. J., Hart, T., Cole, C. R., \& Slowey, P. D. (2015). Salivary cortisol results obtainable within minutes of sample collection correspond with traditional immunoassays. Clinical Therapeutics, 37(3), 505-514. https://doi.org/10.1016/j. clinthera.2015.02.014

Shirtcliff, E. A., Granger, D. A., Schwartz, E., \& Curran, M. J. (2001). Use of salivary biomarkers in biobehavioral research: Cotton-based sample collection methods can interfere with salivary immunoassay results. Psychoneuroendocrinology, 26(2), 165-173. https://doi.org/10.1016/s0306-4530(00)00042-1

Shropshire, S., Quimby, J., \& Cerda, R. (2018). Comparison of single, averaged, and pooled urine protein:creatinine ratios in proteinuric dogs undergoing medical treatment. Journal of Veterinary Internal Medicine, 32(1), 288-294. https://doi.org/10.1111/ jvim. 14872 
Smiley, T., Spelman, L., Lukasik-Braum, M., Mukherjee, J., Kaufman, G., Akiyoshi, D. E., \& Cranfield, M. (2010). Noninvasive saliva collection techniques for free-ranging mountain gorillas and captive eastern gorillas. Journal of Zoo and Wildlife Medicine, 41(2), 201-209. https://doi.org/10.1638/2009-0015R.1

Smith, T. E., \& French, J. A. (1997). Psychosocial stress and urinary cortisol excretion in marmoset monkeys (Callithrix kuhli). Physiology \& Behavior, 62(2), 225232. https://doi.org/10.1016/s0031-9384(97)00103-0

Solberg, C., Holme, S., \& Little, C. (1986). Morphological changes associated with $\mathrm{pH}$ changes during storage of platelet concentrates. Beitrage zu Infusionstherapie und klinische Ernahrung, 15, 107-117.

Srinivasan, M., Muthukumar, S., Saibaba, G., Manikkaraja, C., Abdulkader Akbarsha, M., \& Archunan, G. (2020). Salivary luteinizing hormone: An open window to detect oestrous period in buffalo. Reproduction in Domestic Animals = Zuchthygiene, 55(5), 647-651. https://doi. org/10.1111/rda.13649

Stubsjøen, S. M., Bohlin, J., Dahl, E., Knappe-Poindecker, M., Fjeldaas, T., Lepschy, M., Palme, R., Langbein, J., \& Ropstad, E. (2015). Assessment of chronic stress in sheep (part I): the use of cortisol and cortisone in hair as non-invasive biological markers. Small Ruminant Research, 132, 25-31. https://doi.org/10.1016/j. smallrumres.2015.09.015

Sulakhe, S. J., \& Lautt, W. W. (1987). A characterization of gamma-glutamyltranspeptidase in normal, perinatal, premalignant and malignant rat liver. The International Journal of Biochemistry, 19(1), 23-32. https://doi. org/10.1016/0020-711x(87)90119-4

Taylor, A. E., Keevil, B., \& Huhtaniemi, I. T. (2015). Mass spectrometry and immunoassay: How to measure steroid hormones today and tomorrow. European Journal of Endocrinology, 173(2), D1-D12. https://doi. org/10.1530/EJE-15-0338

Terwissen, C. V., Mastromonaco, G. F., \& Murray, D. L. (2013). Influence of adrenocorticotrophin hormone challenge and external factors (age, sex, and body region) on hair cortisol concentration in Canada lynx (Lynx canadensis). General and Comparative Endocrinology, 194, 162-167. https://doi.org/10.1016/j. ygcen.2013.09.010
Vahl, T. P., Ulrich-Lai, Y. M., Ostrander, M. M., Dolgas, C. M., Elfers, E. E., Seeley, R. J., D’Alessio, D. A., \& Herman, J. P. (2005). Comparative analysis of ACTH and corticosterone sampling methods in rats. American Journal of Physiology. Endocrinology and Metabolism, 289(5), E823-E828. https://doi. org/10.1152/ajpendo.00122.2005

Veronesi, M. C., Comin, A., Meloni, T., Faustini, M., Rota, A., \& Prandi, A. (2015). Coat and claws as new matrices for noninvasive long-term cortisol assessment in dogs from birth up to 30 days of age. Theriogenology, 84(5), 791-796. https://doi. org/10.1016/j.theriogenology.2015.05.013

Wasser, S. K., Monfort, S. L., \& Wildt, D. E. (1991). Rapid extraction of faecal steroids for measuring reproductive cyclicity and early pregnancy in free-ranging yellow baboons (Papio cynocephalus cynocephalus). Journal of Reproduction and Fertility, 92(2), 415-423. https:// doi.org/10.1530/jrf.0.0920415

Wenger-Riggenbach, B., Boretti, F. S., Quante, S., Schellenberg, S., Reusch, C. E., \& Sieber-Ruckstuhl, N. S. (2010). Salivary cortisol concentrations in healthy dogs and dogs with hypercortisolism. Journal of Veterinary Internal Medicine, 24(3), 551-556. https:// doi.org/10.1111/j.1939-1676.2010.0494.x

Wennig, R. (2000). Potential problems with the interpretation of hair analysis results. Forensic Science International, 107(1-3), 5-12. https://doi.org/10.1016/ s0379-0738(99)00146-2

Wheeler, B. C., Tiddi, B., Kalbitzer, U., Visalberghi, E., \& Heistermann, M. (2013). Methodological considerations in the analysis of fecal glucocorticoid metabolites in tufted capuchins (Cebus apella). International Journal of Primatology, 34(5), 879-898. https://doi. org/10.1007/s10764-013-9703-y

Whitten, P. L., Brockman, D. K., \& Stavisky, R. C. (1998). Recent advances in noninvasive techniques to monitor hormone-behavior interactions. American Journal of Physical Anthropology, Suppl 27, 1-23. https://doi. org/10.1002/(sici)1096-8644(1998)107:27+<1::aidajpa2>3.0.co; $2-\mathrm{h}$ 
Wolff, K., Farrell, M., Marsden, J., Monteiro, M. G., Ali, R., Welch, S., \& Strang, J. (1999). A review of biological indicators of illicit drug use, practical considerations and clinical usefulness. Addiction (Abingdon, England), 94(9), 1279-1298. https://doi. org/10.1046/j.1360-0443.1999.94912792.x

Wu, Q., Xiang, S., Wang, W., Zhao, J., Xia, J., Zhen, Y., $\&$ Liu, B. (2018). Species identification of fox-, mink-, dog-, and rabbit-derived ingredients by multiplex PCR and real-time PCR assay. Applied Biochemistry and Biotechnology, 185(1), 1-12. https://doi.org/10.1007/ s12010-017-2621-2

Yamanashi, Y., Morimura, N., Mori, Y., Hayashi, M., \& Suzuki, J. (2013). Cortisol analysis of hair of captive chimpanzees (Pan troglodytes). General and Comparative Endocrinology, 194, 55-63. https://doi. org/10.1016/j.ygcen.2013.08.013

Yang, H. Z., Lan, J., Meng, Y. J., Wan, X. J., \& Han, D. W. (1998). A preliminary study of steroid reproductive hormones in human hair. The Journal of Steroid Biochemistry and Molecular Biology, 67(5-6), 447450. https://doi.org/10.1016/s0960-0760(98)00120-4

Zangheri, M., Cevenini, L., Anfossi, L., Baggiani, C., Simoni, P., Di Nardo, F., \& Roda, A. (2015). A simple and compact smartphone accessory for quantitative chemiluminescence-based lateral flow immunoassay for salivary cortisol detection. Biosensors \& Bioelectronics, 64, 63-68. https://doi.org/10.1016/j. bios.2014.08.048

Ziegler, T. E., \& Wittwer, D. J. (2005). Fecal steroid research in the field and laboratory: improved methods for storage, transport, processing, and analysis. American Journal of Primatology, 67(1), 159-174. https://doi. org/10.1002/ajp.20175 